\title{
Herding behavior in Ramadan and financial crises: the case of the Pakistani stock market
}

\author{
Imran Yousaf ${ }^{1,2^{*}}$, Shoaib Ali ${ }^{2,3}$ and Syed Zulfiqar Ali Shah ${ }^{3}$
}

\author{
* Correspondence: \\ imranyousaf_12@pide.edu.pk \\ ${ }^{1}$ Management Sciences, Capital \\ University of Science and \\ Technology, Islamabad, Pakistan \\ ${ }^{2}$ Air University School of \\ Management, Air University, \\ Islamabad, Pakistan \\ Full list of author information is \\ available at the end of the article
}

\begin{abstract}
This study examines herding behavior in the Pakistani Stock Market under different market conditions, focusing on the Ramadan effect and Crisis period by using data from 2004 to 2014. Two regression models of Christie and Huang (Financ Analysts J 51:31-37, 1995) and Chang et al., (J Bank Finance 24:1651-1679, 2000) are used for herding estimations. Results based on daily stock data reveal that there is an absence of herding behavior during rising (up) and falling (down) market as well as during high and low volatility in market. While herding behavior is detected during low trading volume days. Yearly analysis shows that herding existed during 2005, 2006 and 2007, while it is not evident during rest of the period. However, herding behavior is not detected during Ramadan. Furthermore, during financial crisis of 2007-08, Pakistani Stock Market exhibits herding behavior due to higher uncertainty and information asymmetry.
\end{abstract}

Keywords: Herding behavior, Financial crisis, Ramadan effect, Stock markets

\section{Introduction}

In conventional finance, nature of human being is assumed to be rational and rational individual takes decision on the basis of reason or logic. But in reality, most of the time individuals follow the other's decisions without any reason (Easley and Kleinberg 2012). So, when individuals imitate others in most of their decisions by bypassing their own judgment or decision, then how can all individuals claim to be rational. Herding is one of the important behavior of human being which explain the deviation of human being from the rational decision making by following others.

Malkiel and Fama (1970) claim that financial markets are efficient and security prices fully reflect all available information at any time; and investors are rational in these efficient markets. But reality is somewhat different and investor's decisions are governed by their emotions and individual behaves irrationally (Shiller 2003) because their decisions are effected by their emotions. Kahneman and Tversky (1979) argue that human psychology is important to understand the financial markets. Individuals behave irrationally due to herd behavior in financial markets. There are several effects of herd behavior on financial markets. Olsen (1996) argue that it's difficult to forecast in presence of herding behavior, as stock prices do not reflect their fundamental values in presence of herding behavior. This deviation of prices from fundamental values reflects the inefficiency of the markets.

(c) The Author(s). 2018 Open Access This article is distributed under the terms of the Creative Commons Attribution 4.0 International License (http://creativecommons.org/licenses/by/4.0/), which permits unrestricted use, distribution, and reproduction in any medium, provided you give appropriate credit to the original author(s) and the source, provide a link to the Creative Commons license, and indicate if changes were made. 
This study examines the herding behavior with respect to three aspects, which are discussed below one by one. First, this study examines the herding during different market conditions, e.g. rising (up) and falling (down) market, High and low trading volume as well as high and low market volatility. This study uses the two regression models of (Christie and Huang 1995) and (Chang et al. 2000) for herding estimations. Extreme herding results in mispricing and this phenomena ultimately leads to financial crisis (Hwang and Salmon 2004). So, pre-crisis herding leads towards crisis.

Second, this study examines the herding behavior during Month of Ramadan. Emotions and mood of individual play a crucial role in investor's behavior (Loewenstein et al. 2001) and mood of individual is also shaped by religious occasions. Wright and Bower (1992) argue that investors can become more optimistic and also willing to take riskier investment decisions in positive mood state. In literature, social mood is gauged by the weather (Saunders 1993), belief related to Friday 13th (Dowling and Lucey 2005) and biorhythms (Kamstra et al. 2003). Some studies has examined the effect of religion on the mood and behavior of individuals; Frieder and Subrahmanyam (2004) studied the effect of Jewish High Holidays on US dollar volume and stock returns. Positive stock returns are observed during these holidays. Pantzalis and Ucar (2014) find that behavior of investors in US is significantly affected during Easter week holidays. While many studies have investigated the stock returns in Muslim Countries; and identified the "positive mood effects of Ramadan" on investor's behavior (Al-Hajieh et al. 2011; Al-Khazali 2014). These studies find that stock returns are higher during Ramadan as compare to non-Ramadan days. Motivated by this evidence, this study examines the presence of herding behavior during Ramadan days in stock market of Pakistan.

Third, this study examines the herding behavior during crisis period. Christie and Huang (1995) suggest that herding intensity rises during the times of market stress. Uncertainty regarding value of asset can increase during financial crisis and ultimately investors show herd behavior. Chiang and Zheng (2010) find that herding increases during financial crisis. Fourth, this study also detects herding during crisis period. So, herding behavior can be different in crisis and non-crisis time period. Motivated by the evidence, this study examines the herding behavior during global financial crisis of 2008.

Overall, this study examines herding in the Pakistani Stock Exchange under different market conditions, focusing on the Ramadan effect and Crisis period. Our findings also provide insight into foreign and local investors while taking investment decision in different market conditions. Findings will also provide important insights to the regulators of the equity market of Pakistan for stability of market during a period of crisis. Furthermore, this study will also add literature to the area of "Religion and Finance".

\section{Importance of Pakistani stock market}

The stock market of Pakistan has provided very high returns to investors as compared to Indian and Chinese equity markets in 2016 (Mourdoukoutas 2016). In 2016, the market was declared as the best performing stock market in Asia, according to a basket of 26 peers tracked by Bloomberg (Kim and Mangi 2016). MSCI Incorporation reclassify Pakistan as part of its benchmark emerging-market index from May 2016 (Nauman 2016). The standard deviation of stock market returns is also high, so volatility of market is high as compare many other Asian Markets (Hamid et al. 2017). So, it's 
important for the foreign and local investors to become familiar with the behavior of investors especially herd behavior during Ramadan and crisis time period in stock market of Pakistan.

To fulfill the objective of the study, the rest of the research paper is divided into sections. In Section (Literature review), this study provides the comprehensive review of literature. In Section (Research methodology), this study presents the research methodology of the study and this section has further divided into two subsections. Data description is presented in subsection (Data description) and model of study is presented in Subsection Model. In Section (Empirical Results), this study provides the empirical results of the study and this section further divided into two subsections. Summary statistics is presented in Subsection (Summary Statistics) and regression analysis is demonstrated into Subsection (Regression Results). In chapter 5, this study provides the conclusions of the study. In section 6, this study presents the references of the study.

\section{Literature review}

Herding behavior is most of the time associated with the financial markets; and one of the major concepts of cognitive economics (Parker and Prechter 2005). Herding behavior is explained in literature from different perspectives. Humans follow the behavior of others in their many daily life decisions. And same happens in financial markets, investors follow the behavior of other groups of investors or large investors. Shiller (2003) argue that humans show herd behavior since the first ancient tribes and group based migrations. Easley and Kleinberg (2012) describes that humans imitate the behaviors of others, even if there is no solid reason or informational cause to do so.

Same as (Freud 1922) have done research on group psychology; and found that Humans act in accordance with a crowd that has strong leader. His study also shows that when a group is formed then authority is chosen automatically. His findings show that herd instinct restricts one's ability to take decisions on the basis of their own information and emotion. When applied it in the financial market, (Keynes 1937) argues that markets are run by animal spirit; and serious issue with the animal spirit is that most investors are incapable of processing the new information logically; and due to this incapability, investors ignores their personal information and follow the other participants of the markets. Bikhchandani and Sharma (2000) argue that herd is created when investors allow their decisions to be effected by others; and when investors acknowledge the decisions of others. Investors respond on the basis of signals received from other investors and these signals can be misleading because speculators create impulses in the market (Froot et al. 1992).

Investors can show herd behavior to lower their intensity of regret. Scharfstein and Stein (1990) argue that fund managers ignore private information in order to maintain their reputations, and instead imitate others' investment strategies. Regret intensity is high for individuals when failure occurs to individual alone as compared to failure occured to several individuals. So, this shows that individuals are afraid to be left alone with their convictions, that's why individuals show herd behavior (Yahyazadehfar et al. 1985). This phenomena refers to the regret aversion bias. However (Tan et al. 2008) argue that when investors show herd behavior then prices are different from fundamental values. So, due to this deviation of price from fundamental value, some experts might spot profitable trading opportunities. 
In behavioral finance based literature, herding is often used to describe the correlation in trades resulting from interactions between investors. This behavior is well thought-out to be rational for less specialized investors. They mimic, or try to mimic the activities of successful investors, since they are not specialized or using their own information/ knowledge would incur a higher cost (Chiang and Zheng 2010). Thus the investors follow the similar trading direction over a period of time (Nofsinger and Sias, 1999). While (Keynes 1937) claims that fundamentals facts and data are most of the time neglected or even not relevant to markets. He asserts that investors take their decisions on the basis of speculation and rumors, without applying critical thinking.

Lakonishok et al. (1992) find that herding behavior is more obvious in small market capitalization stocks as compared to stocks having large market capitalization. This happens because there is lack of publicly available information related to low market capitalization stock, so encouraging market participants to follow the market consensus. They notice that homogeneous and simultaneous reaction is common among investors of small capitalization stocks, especially after price movements and news announcements. On the other hand, they observe that investors with investments in large capitalization stocks are able to take decision on the basis of their own analysis due to high transparency.

\section{Herding behavior during Ramadan}

Religion plays important role in financial decision making, i.e. religion affects the individual's propensity to save (Renneboog and Spaenjers 2012), risk attitude (Kumar et al., 2011) and the decision to invest in stock (Renneboog and Spaenjers 2012). While on aggregate level, religion affects the creditor protection (Stulz and Williamson 2003) and economic growth (Barro and Mccleary 2003). The month of Ramadan is very important in Islamic religion. This month is celebrated by more than 1.7 billion Muslims all over the world.

During Ramadan, Muslims do not drink, eat, smoke or having sensual pleasure from dawn (Fajar) till sunset (Maghrib). Muslims follow the defined fasting and prayers timetable during Ramadan. This Holy month disciplines a Muslim's life in specific ways. These similar routines during Ramadan lead towards certain similarities in Muslims in day to day conducts. Increased level of social interaction and Low level of anxiety is observed in Muslims during month of Ramadan (Daradkeh 1992; Knerr and Pearl 2008). Muslim investors can show herd during Ramadan due to their similarities in routine, low level of anxiety and higher social interaction. These three factors may leads towards the herding behavior during month of Ramadan.

Few finance studies has examined the mood-effect of Ramadan. Seyyed et al. (2005) examine the impact of the holy month of Ramadan on Stock returns in Saudi Arabia; and find that there is no significant difference between the stock returns during Ramadan and Non-Ramadan days. Al-Hajieh et al. (2011) find that high stock returns are observed during month of Ramadan as compare to Non Ramadan days for majority of countries from Middle Eastern countries. This study uses a data of eight Middle Eastern Countries from 1992 to 2007. Białkowski et al. (2012) find that the stock returns are higher during month of Ramadan as compare to Non Ramadan Months in majority of 14 Muslim countries. Al-Khazali (2014) also finds that the higher stock returns are observed in Ramadan in majority of 15 Muslim Countries. So, Ramadan prompts the feelings of solidarity and social identity, which leads toward the increases 
in investors' optimism; and ultimately it effects their investment decisions. Motivating by this evidence, this study examines the herding behavior during Month of Ramadan in stock market of Muslim country of Pakistan.

\section{Herding behavior during financial crisis}

Many of the definitions are proposed to detect herding behavior in literature of herding behavior. According to these definitions, there are two different forms of herding: first is rational herding and second is irrational herding. According to rational herd behavior perspective, herding behavior is associated with the situation in which investors are tried to restore their returns by ignoring voluntarily their own analysis; and replicate or follow another manager's decision who possesses a more reliable source of information or who has high level of analysis competencies of investment decisions Bikhchandani and Sharma (2000). Sometimes, it's more difficult to distinguish between irrational herding behavior and rational herding behavior. Most of the studies in literature have focused upon rational herding behavior.

According to irrational herding perspective, herding behavior is associated with collective actions of individuals under uncertain conditions. The investors show herd behavior to reduce uncertainty and to increase their confidence in investment returns (Devenow and Welch 1996). The happening of financial crisis or bubbles can be explained by the irrational behavior of investors in the stock markets, when investors follow the other investors or groups in decision making (Malkiel 2003). Shiller (2003) claims that future bubbles could be eliminated by considering the human behavior to understand financial markets.

Many of empirical studies examine the herd behavior during financial crisis. There were many financial crisis occurred in past such as US stock market crash in 1987, Asian financial crises in 1997 and financial crisis of 2007-08. Many studies show that high correlation exists between different market returns during these crises. Like (Hwang and Salmon 2004) find that Asian crisis was influenced the markets of South Korea, UK and US. In addition, this study finds that strong evidence of herding during the pre-crisis. Kremer and Nautz (2013a, b) find that in case of Germany, herding reduces during the financial crisis. Also (Hwang and Salmon 2004) find that herding intensity was decreased during the Asian and the Russian crisis in the nineties. On the other hand, (Chiang and Zheng 2010) find that herding intensity increases during financial crisis. So, various types of herding evidences exist during crisis in different markets of the world. Motivating by this evidence, this study examines the herding behavior in stock market of Pakistan during financial crisis of 2008.

\section{Presence of herding behavior in individual markets}

Herd behavior is examined in different financial markets of the world and find mixed type of evidence about herd behavior. Some studies examine herd behavior at local level financial markets and some at global level. Hwang and Salmon (2004) find that markets of developed countries like UK and USA show fewer herding activities as compared to markets of emerging economies such as South Korea. A recent study (Galariotis et al. 2015) find that herding exists in USA market when government announces macroeconomic information in USA. In contrast, (Barberis et al. 2005) find that herding is not existed in USA 
financial market. Henker et al. (2006) find that there is no evidence of herding in Australia. In contrast, contradictory evidences are also existed related to herd in developed countries like USA and many others. There is no evidence of herding in Hong Kong (Chang et al. 2000).

Now we enter into developing world to find an evidence of herd. Chang et al. (2000) find that herding exists in Taiwan and South Korean financial markets. Herd exists in Asian countries due to some reasons, two reasons of them are as follows. First, financial markets of Asian countries show herd behavior due to their economic conditions. Second, sufficient information regarding most of the firms is not available in these countries, so investors rely more on macroeconomic information for investment decision making (Chang et al. 2000). Herd exists in Indian and Chinese stock markets (Lao and Singh 2011).

Demirer and Kutan (2006) find that herding does not exist in Chinese financial markets. While in contrast, (Tan et al. 2008) find that herding exist in the Chinese financial markets in both fall and rising conditions of the financial markets of China. Fu (2010) finds that herd behavior exist during down market days and (Lao and Singh 2011) during low trading volume in Chinese financial markets, while herd behavior exists during rising conditions of Indian financial market.

Fewer studies explore the herding behavior in Pakistani stock market. Javaira and Hassan (2015) find that herding does not exist in Pakistani stock market from 2002 to 2007 and during liquidity crisis of 2005. While (Javed et al. 2013) also find that there is no significant evidence of herding behavior in Pakistani stock market during extreme market conditions. Malik and Elahi (2014) find that there is an evidence of herding behavior in Pakistani Stock market during normal and both bullish and bearish market conditions. This study uses a Quantile regression analysis to explore herd behavior. Shah et al. (2017) find that there is a presence of herding behavior between the large capitalizations based firms during extreme market movements. Also firms show herd behavior when market experience a $5 \%$ negative returns. Further, there is no evidence of herd toward market index by individual firms. Zafar and Hassan (2016) find that there is a presence of herd behavior during both up and down market conditions in stock market of Pakistan. So, there is a further need to explore herding behavior in stock market of developing country like Pakistan. That's why, this study will detect the herding behavior in stock market of Pakistan during Ramadan and Financial crisis of 2008.

\section{Research methodology}

Data description

This study examines the herding behavior in stock market of Pakistan. The population of study consisted of all the listed firms on Karachi Stock Exchange (KSE) and study's sample consists of 101 firms listed on Karachi Stock Exchange. The daily stock prices data is used for analysis and sample period is from 2004 to 2014. The data is further divided into two categories, crisis and non-crisis period, while crisis data refers to the data from 2007 to September-2008 and non crisis data refers to the remaining data of sample. This study uses period of crisis same as used by (Erkens et al. 2012) in his study of corporate Governance during financial crisis. The stock prices data is taken from the website www.brecorder.com. 
Model

There are different methods existed to detect herding behavior of investors in the financial markets. This study uses two methods to detect the herding behavior in the market. First, (Christie and Huang 1995) suggest a method to detect herding behavior in market through dispersion. Christie and Huang (1995) argue that individual investors may follow the behavior of market by ignoring their own information regarding stock prices during large price movements. Chang et al. (2000) also uses the similar model for measuring the herding behavior. When investors follow the behavior of market then individual stock returns are close to market returns and ultimately level of dispersion decreases. So, herd exists when dispersion is lower or individual stock returns are close to the market returns. The dispersion of individual stock returns from the market returns is measured through cross sectional standard deviation (CSSD). Cross sectional standard deviation is defined as:

$$
C S S D_{t}=\sqrt{\frac{\sum_{i=1}^{N}\left(R_{i t}-R_{m t}\right)^{2}}{N-1}}
$$

Where $\operatorname{CSSD}_{t}$ is the cross sectional standard deviation on day $t, R_{i t}$ is the stock returns $i$ at time $t, \mathrm{R}_{\mathrm{mt}}$ is the market returns $m$ at time $t$ and $\mathrm{N}$ is the number of stocks. Christie and Huang (1995) use the following model to detect herding behavior during extreme market conditions:

$$
\operatorname{CSSD}_{t}=\alpha+\beta_{L} D_{t}^{L}+\beta_{U} D_{t}^{U}+e_{t}
$$

$D_{t}^{L}$ refers to the dummy variable which is equal to 1 when daily market return lies in the extreme lower x percent of the observations and 0 otherwise. $D_{t}^{U}$ refers to the dummy variable which is equal to 1 when daily market return lies in the extreme upper $\mathrm{x}$ percent of the observations and 0 otherwise. For $\mathrm{x}$ percent, this study uses extreme $1 \%, 5 \%$ and $10 \%$ observation in upper or lower tail of market returns distribution. According to this model, herding exists in market if coefficient of $\beta_{L}$ and $\beta_{U}$ are negative. While there is an absence of herding if coefficients of $\beta_{L}$ and $\beta_{U}$ are positive. These coefficients are positive when there is presence of high volatility among individual stock returns.

Second, (Chang et al. 2000) suggest another model to detect the herding behavior in financial markets. Through this model, herding could be detected during less extreme market movements. Instead of CSSD, this model uses the cross sectional absolute deviations (CSAD) and defined as:

$$
C S A D_{t}=\frac{\sum_{i=1}^{N}\left|R_{i t}-R_{m t}\right|}{N}
$$

$R_{i t}, R_{m t}$ and $N$ are same as defined in CSSD based model. Chang et al. (2000) demonstrate that according to assumptions of capital asset pricing model (CAPM), there should be a linear relationship between dispersion of individual stock returns and market returns. And if there is any evidence of non-linear relationship between CSAD and market returns then it could be interpreted as an evidence of herding behavior. To test this non-linearity, (Chang et al. 2000) suggest the following regression model: 


$$
C S A D_{t}=\alpha+\beta_{1}\left|R_{m t}\right|+\beta_{2}\left(R_{m t}\right)^{2}+e_{t}
$$

According to rational asset pricing model, $\beta_{1}$ should be positive and $\beta_{2}$ should be zero. While herding exists, if $\beta_{2}$ is negative in model of (Chang et al. 2000). So, herding exists when there is negative and non-linear relationship between market returns and $\operatorname{CSAD}_{\mathrm{t}}$. It means that cross sectional absolute deviation can decrease or increase at decreasing rate if the stock market returns are large. And positive $\beta_{2}$ shows that market returns increase then CSAD also increases, so it's also an evidence of absence of herding in financial markets.

Chang et al. (2000) suggest another two regression model to detect the herding during market up and market down:

$$
\begin{aligned}
& C S A D_{t}^{U p}=\alpha+\beta_{1}^{U P} R_{m t}^{U P}+\beta_{2}^{U P}\left(R_{m t}^{U P}\right)^{2}+e_{t} \\
& C S A D_{t}^{\text {Down }}=\alpha+\beta_{1}^{\text {Down }}\left|R_{m t}^{\text {Down }}\right|+\beta_{2}^{\text {Down }}\left(R_{m t}^{\text {Down }}\right)^{2}+e_{t}
\end{aligned}
$$

Here $R_{m t}^{U P}$ refers to the positive market returns while $R_{m t}^{D o w n}$ refers to the negative market returns on day $t$. $C S A D_{t}^{U p}$ refers to the CSAD when market returns are positive while $C S A D_{t}^{\text {Down }}$ refers to the CSAD when market returns are negative at day $t$. Herding exists during bull market if $\beta_{2}^{U P}$ is negative. And herding exists during bear market, if $\beta_{2}^{\text {Down }}$ is negative.

Herding behavior might be different during high and low trading volumes. Tan et al. (2008) examined the existence of herd behavior during high and low trading volume. If trading volume of day " $t$ " is greater as compare to the moving average of last 30 days trading volume then trading volume is considered to be high and vice versa.

$$
\begin{aligned}
& C S A D^{V-H I G H}=\beta_{0}+\beta_{1}^{V-H I G H}\left|R_{m, t}^{V-H I G H}\right|+\beta_{2}^{V-H I G H}\left(R_{m, t}^{V-H I G H}\right)^{2}+\varepsilon_{t} \\
& C S A D^{V-L O W}=\beta_{0}+\beta_{1}^{V-L O W}\left|R_{m, t}^{V-L O W}\right|+\beta_{2}^{V-L O W}\left(R_{m, t}^{V-L O W}\right)^{2}+\varepsilon_{t}
\end{aligned}
$$

V-high and V-low denote the high and low trading volumes.

Market volatility can affect the herding behavior of investors. Tan et al. (2008) examine the herding behavior during high and low market volatility. If market volatility of day " $\mathrm{t}$ " is greater as compare to the moving average of last 30 days market volatility then market volatility is considered to be high and vice versa.

$$
\begin{aligned}
& C S A D_{t}^{\sigma^{2}-H i g h}=\beta_{0}+\beta_{1}^{\sigma^{2}-H I G H}\left|R_{m, t}^{\sigma^{2}-H i g h}\right|+\beta_{2}^{\sigma^{2}-H I G H}\left(R_{m, t}^{\sigma^{2}-H i g h}\right)^{2}+\varepsilon_{t} \\
& C S A D_{t}^{\sigma^{2}-\text { Low }}=\beta_{0}+\beta_{1}^{\sigma^{2}-L O W}\left|R_{m, t}^{\sigma^{2}-\text { Low }}\right|+\beta_{2}^{\sigma^{2}-L O W}\left(R_{m, t}^{\sigma^{2}-\text { Low }}\right)^{2}+\varepsilon_{t}
\end{aligned}
$$

$\sigma^{2}$-High and $\sigma^{2}$ - Low denote the high and low market volatility.

This study also examines the herding behavior during Ramadan. Ramadan is the holy month of Muslims and majority of the investors are Muslims in Pakistan. So, this study uses the dummy (DM) for Ramadan days and zero otherwise. This study estimate the following equation:

$$
C S A D_{t}=\beta_{0}+\beta_{1}\left|R_{m, t}\right|+\beta_{2}\left(R_{m, t}\right)^{2}+\beta_{3}\left(R_{m, t}\right)^{2} * D M_{t}+\varepsilon_{t}
$$

Tan et al. (2008) examine the existence of herd behavior during Asian financial crisis. This study examines the existence of herd behavior in Pakistani stock market during financial crisis of 2008. 


$$
C S A D_{t}=\beta_{0}+\beta_{1}\left|R_{m, t}\right|+\beta_{2}\left(R_{m, t}\right)^{2}+\beta_{3}\left(R_{m, t}\right)^{2} * D M_{t}+\varepsilon_{t}
$$

Dummy variable "DM" is used to denote the financial crisis, it takes value 1 during 2007 to Sep-2008 financial crisis and zero otherwise. Extreme events (like financial crisis) might have strong impact on the individual investors (Kahneman and Tversky 1972). Christie and Huang (1995) also recommends that herding is more prevalent during time of market stress; and suggests that extreme return movements persistently occur in crisis period. So, investors can behave differently during crisis and non crisis time periods. Investors can follow the other investors because payoff against investments are tremendously uncertain during crisis.

\section{Empirical results}

\section{Summary Statistics}

Table 1 shows the summary statistics of cross section standard deviation, cross section absolute deviation, and market returns. Summary statistics show that the daily average CSSD is 0.0311 , while maximum value is 0.4056 and minimum value is 0.0014 . So, there is huge difference between minimum and maximum value of CSSD and this huge difference indicates higher volatility in CSSD. On the other hand, average daily CSAD is 0.0194 while maximum and minimum values are 0.1145 and 0.0003 respectively. The average daily market return is 0.0003 while maximum and minimum values are 0.0522 and -0.0786 respectively.

\section{Regression results}

This study uses regression analysis to examine herding in the stock market. This regression analysis is classified into three categories to examine herd. First, this study investigates the herding during different market conditions by using the model of (Christie and Huang 1995). Second, this study examines the herding by using regression model of (Chang et al. 2000). Third, this study analyzes the presence of herding behavior during Pre and Post crisis of 2007-2008. All equations are estimated using Newey West Consistent Estimators.

\section{Cross sectional standard deviation}

To test the presence of herding in stock market of Pakistan, this study uses the regression model of (Christie and Huang 1995). Table 2 summarizes the regression results for CSSD by using three criterion, $1 \%, 5 \%$ and $10 \%$. In $1 \%$ criterion, upper and lower $1 \%$ market returns observations use for dummy variables $D_{U}$ and $D_{L}$. The regression results shows that both coefficients $\beta_{\mathrm{L}}$ and $\beta_{\mathrm{U}}$ are positive and significant at all criterion of $1 \%, 5 \%$ and $10 \%$. According to model of (Christie and Huang 1995), positive

Table 1 Summary statistics

\begin{tabular}{llll}
\hline Summary stat & CSSD & CSAD & RM \\
\hline Mean & 0.0311 & 0.0194 & 0.0003 \\
Median & 0.0275 & 0.0184 & 0.0010 \\
Maximum & 0.4056 & 0.1145 & 0.0522 \\
Minimum & 0.0014 & 0.0003 & -0.0786 \\
Std. Dev. & 0.0205 & 0.0070 & 0.0105 \\
\hline
\end{tabular}


Table 2 Regression of $\mathrm{CSSD}_{\mathrm{t}}$

\begin{tabular}{llllll}
\hline Criterion & Constant & $D_{U}$ & $D_{L}$ & Adj. $R^{2}$ & F-Statistic \\
\hline $1 \%$ & $0.0303(79.50)^{* * *}$ & $0.0436(11.71)^{* * *}$ & $0.0420(11.08)^{* * *}$ & 0.0865 & $(128.6)^{* * *}$ \\
$5 \%$ & $0.0294(73.13)^{* * *}$ & $0.0161(9.240)^{* * *}$ & $0.0192(10.97)^{* * *}$ & 0.0670 & $(97.80)^{* * *}$ \\
$10 \%$ & $0.0285(66.896)^{* * *}$ & $0.0114(9.005)^{* * *}$ & $0.0154(12.07)^{* * *}$ & 0.0701 & $(102.5)^{* * *}$ \\
\hline
\end{tabular}

*** means that variable is significant at $1 \%$ level of significance

coefficients of $\beta_{\mathrm{L}}$ and $\beta_{\mathrm{U}}$ means that there is no evidence of herding during extreme market movements. So, these results show that there is no evidence of herding behavior in Karachi Stock Exchange. Herding behavior is not evident during extreme market movement while using full sample period.

\section{Cross section absolute deviation}

This study uses the regression model of (Chang et al. 2000) to examine the presence of herding in stock market of Pakistan. Table 3 summarizes the regression results for CSAD by using three ways. First, this study uses CSAD of full sample to detect herding in stock market. Second, this study uses the $\mathrm{CSAD}_{\mathrm{UP}}$ to examine herding during bull market. Third, this study uses the $\mathrm{CSAD}_{\mathrm{DOWN}}$ to examine the herding during bear market condition. The regression results of total market sample shows that coefficient of $\left[\mathrm{R}_{\mathrm{m}, \mathrm{t}}\right]^{2}$ is positive and significant at significance level of $1 \%$. According to regression model of (Chang et al. 2000), coefficient of $\left[R_{m, t}\right]^{2}$ is significantly negative, which means that there is presence of herding in market and vice versa. As $\beta 2$ is positive in total market returns sample, so there is an absence of herding in Stock market of Pakistan. As $\beta 2$ is negative but highly insignificant during Up market returns, so there is an absence of herding during positive market returns. And $\beta 2$ is positive and highly significant during down market, so there is an absence of herding during down market returns. Overall, there is no significant evidence of herding during total, up and down market returns conditions in stock market of Pakistan. So, herding behavior is not evident during less extreme market movements when using full sample period. Both CSSD and CSAD conclude that there is no evidence of herding in full sample period. So, both methods conclude with the same results and imply that there is an absence of herding during high as well as lower extreme market movements in full sample.

Table 4 summarizes the regression results for herding behavior during high and low trading volume. As $\beta 2$ is positive and significant during high trading volume in market, so there is an absence of herding during high trading volumes. And $\beta 2$ is negative and highly significant during low trading volume in market, so there is a presence of herding during low trading volumes. So, herding exists during low volume trading in Pakistan.

Table 3 Herding behavior during up and down market

\begin{tabular}{llllll}
\hline Market & Constant & $\left|R_{m, t}\right|$ & {$\left[R_{m, t}\right]^{2}$} & Adj. $R^{2}$ & F-Statistic \\
\hline Total Market (Eq. 4) & $0.0154(84.16)^{* * *}$ & $0.4832(15.76)^{* * *}$ & $3.3164(3.928)^{* * *}$ & 0.3981 & $(892.2)^{* * *}$ \\
Up Market (Eq. 5) & $0.0153(64.11)^{* * *}$ & $0.5932(13.54)^{* * *}$ & $\begin{array}{l}-0.0571 \\
(-0.041)\end{array}$ & 0.3697 & $(442.9)^{* * *}$ \\
Down Market (Eq. 6) & $0.0153(53.01)^{* * *}$ & $0.4093(9.101)^{* * *}$ & $5.3498(4.631)^{* * *}$ & 0.4282 & $(445.2)^{* * *}$ \\
\hline
\end{tabular}

***means that variable is significant at $1 \%$ level of significance. () contains the t-statistics 
Table 4 Herding behavior during high and low trading volume

\begin{tabular}{llllll}
\hline Trading Volume & Constant & $\left|\mathrm{R}_{\mathrm{m}, \mathrm{t}}\right|$ & {$\left[\mathrm{R}_{\mathrm{m}, \mathrm{t}}\right]^{2}$} & Adj. $\mathrm{R}^{2}$ & F-Statistic \\
\hline High Trading Volume (Eq. 7) & $0.0171{ }^{* * * *}$ & 0.3535 & 9.1453 & 0.4505 & $(476.2)^{* * * *}$ \\
& $(55.70)^{* * * *}$ & $(7.781)^{* * *}$ & $(8.104)^{* * *}$ & & \\
Low Trading Volume (Eq. 8) & 0.0137 & 0.7352 & -7.6746 & 0.3983 & $(499.1)^{* * *}$ \\
& $(64.72)^{* * *}$ & $(17.86)^{* * *}$ & $(-6.162)^{* * *}$ & & \\
\hline
\end{tabular}

***means that variable is significant at $1 \%$ level of significance. () contains the t-statistics

Table 5 summarizes the regression results for herding behavior during high and low volatility. As $\beta 2$ is negative and insignificant during high market volatility, so there is an absence of herding during high market volatility. And $\beta 2$ is negative and insignificant during low market volatility, so there is an absence of herding during low market volatility. So, there is no evidence of herding during high and low market volatility.

This study also examines the herding behavior during shorter periods of 1 year. Regression model of (Chang et al. 2000) is used to detect the year wise herding in stock market. Table 6 shows the year wise regression results of CSAD. The results show that $\beta_{2}$ is negative between 2004 and 08 and during 2011 and 2014. But, $\beta_{2}$ is negative and statistically significant during 2005, 2006 and 2007. So, these findings show a presence of herding behavior during 2005, 2006 and 2007. While $\beta_{2}$ is positive during 2009, 2010, 2012 and 2013. But $\beta_{2}$ is positive and statistically significant during 2012. In short, there is a presence of herding behavior in some years; and there is an absence of herding in some years.

\section{Herding during Ramadan and financial crisis}

Some events may affect the herding behavior of the investors, this study examines the herding behavior during Ramadan and 2007-08 financial crisis. Table 7 summarizes the regression results for herding behavior during Ramadan and Financial Crisis. As $\beta 3$ is negative and insignificant during Ramadan, so herding behavior is not influenced by month of Ramadan. And $\beta 3$ is negative and significant during 2008 financial crisis, so herding behavior is influenced by the financial crisis. So, there is an evidence of herding during financial crisis of 2007-08 due to asymmetry of information between investors.

Return's volatility in financial markets increases due to herd behavior and extreme volatility results in financial crisis. Chiang and Zheng (2010) find that herding is evident during financial crisis. So, our results are consistent with the findings of (Chiang and Zheng 2010). Investors show herd behavior during market stress condition (Christie and Huang 1995) because uncertainty becomes high during market crisis.

\section{Conclusion}

This study examines herding behavior in the Pakistani Stock Exchange under different market conditions, focusing on the Ramadan effect and Crisis period. The empirical

Table 5 Herding behavior during high and low market volataity

\begin{tabular}{llllll}
\hline Volatility & Constant & $\mid \mathrm{R}_{\mathrm{m}, \mathrm{t}}$ & {$\left[\mathrm{R}_{\mathrm{m}, \mathrm{t}^{2}}\right.$} & Adj. $\mathrm{R}^{2}$ & F-Statistic \\
\hline High Volatility (Eq. 9) & $0.0156^{* * *}$ & $0.5504^{* * *}$ & -1.6275 & 0.4089 & $(409.9)^{* * *}$ \\
& $(55.73)^{* *}$ & $(11.72)^{* *}$ & $(-1.215)$ & & \\
Low Volatility (Eq. 10) & 0.0144 & 0.6116 & -1.771 & 0.3215 & $(499.1)^{* * *}$ \\
& $(63.75)^{* * *}$ & $(12.97)^{* * *}$ & $(-1.010)$ & & \\
\hline
\end{tabular}

***means that variable is significant at $1 \%$ level of significance. () contains the t-statistics 
Table 6 Yearly Regression results for $\mathrm{CSAD}_{\mathrm{t}}$

\begin{tabular}{|c|c|c|c|c|c|}
\hline Year & Constant & $\left|R_{m, t}\right|$ & {$\left[R_{m, t}\right]^{2}$} & Adj. $R^{2}$ & F-Statistic \\
\hline 2004 & $0.0138(30.53)^{* * *}$ & $0.6372(6.568)^{* * *}$ & $\begin{array}{l}-3.4716 \\
(-0.901)\end{array}$ & 0.4688 & $(109.9)^{* * *}$ \\
\hline 2005 & $0.0152(35.17)^{* * * *}$ & $0.5572(7.181)^{* * * *}$ & $\begin{array}{l}-4.553 \\
(-1.967)^{* *}\end{array}$ & 0.4851 & $(117.3)^{* * *}$ \\
\hline 2006 & $0.0146(34.30)^{* * *}$ & $0.5365(6.473)^{* * *}$ & $\begin{array}{l}-4.6089 \\
(-1.660)^{*}\end{array}$ & 0.4791 & $(110.4)^{* * *}$ \\
\hline 2007 & $0.0145(38.83)^{* * *}$ & $0.5825(8.129)^{* * *}$ & $\begin{array}{l}-7.2729 \\
(-3.355)^{* * *}\end{array}$ & 0.3890 & $(78.36)^{* * *}$ \\
\hline 2008 & $0.0098(11.07)^{* * *}$ & $0.9695(8.262)^{* * *}$ & $\begin{array}{l}-0.8719 \\
(-0.366)\end{array}$ & 0.5807 & $(162.3)^{* * *}$ \\
\hline 2009 & $0.0209(24.68)^{* * *}$ & $0.5105(3.872)^{* * *}$ & $\begin{array}{l}0.9000 \\
(0.239)\end{array}$ & 0.3432 & $(65.02)^{* * * *}$ \\
\hline 2010 & $0.0209(53.34)^{* * * *}$ & $0.2109(2.954)^{* * *}$ & $\begin{array}{l}2.8142 \\
(1.286)\end{array}$ & 0.2673 & $(46.07)^{* * *}$ \\
\hline 2011 & $0.0136(31.51)^{* * *}$ & $0.7073(7.632)^{* * *}$ & $\begin{array}{l}-3.9702 \\
(-1.200)\end{array}$ & 0.4204 & $(90.60)^{* * *}$ \\
\hline 2012 & $0.0167(32.94)^{* * *}$ & $\begin{array}{l}0.0752 \\
(0.738)\end{array}$ & $34.041(9.921)^{* * *}$ & 0.6686 & $(251.2)^{* * *}$ \\
\hline 2013 & $0.0156(50.09)^{* * * *}$ & $0.2861(5.075)^{* * *}$ & $\begin{array}{l}2.8878 \\
(1.508)\end{array}$ & 0.4223 & $(90.94)^{* * *}$ \\
\hline 2014 & $0.0155(40.96)^{* * *}$ & $0.3796(5.470)^{* * *}$ & $\begin{array}{l}-2.5306 \\
(-1.199)\end{array}$ & 0.2450 & $(40.44)^{* * *}$ \\
\hline
\end{tabular}

****** and ${ }^{*}$ denotes to the significance at the level of $1 \%, 5 \%$ and $10 \%$ respectively. () contains the t-statistics

findings illustrates that there is an absence of herding behavior in Karachi Stock Exchange by using regression model of (Christie and Huang 1995). So, there is no evidence of herding during extreme upper and lower market returns.

By using regression model of (Chang et al. 2000), the study does not detect herding behavior when full market returns data is used. Also herding behavior does not exist during rising and falling market as well as during high and low volatility in market. Herding behavior is detected during low volume trading in Pakistan. Yearly analysis of herding behavior shows that herding is existed during 2005, 2006 and 2007 while there is no significant evidence of herding in remaining years of sample. However, study find that herding behavior is not influenced by month of Ramadan.

Furthermore, during financial crisis of 2007-08, Pakistani Stock Market exhibits herding behavior due to higher uncertainty and information asymmetry. So, overall this study concludes that all investors are not perfectly rational, as they show herd behavior during low trading volume days and in crisis time period, which means that stock market is inefficient during crisis time period. From practitioners' perspective, this study contain implications for institutional and retail investors.

Table 7 Herding behavior during Ramazan and Financial Crisis

\begin{tabular}{lllllll}
\hline Event & Constant & $\left|R_{m, t}\right|$ & {$\left[R_{m, t}\right]^{2}$} & {$\left[R_{m, t}\right]^{*} D$} & Adj. $R^{2}$ & F-Statistic \\
\hline Ramzan & 0.0154 & 0.4848 & 3.3582 & -2.872 & 0.3983 & $(595.6)^{* * *}$ \\
(Eq. 11) & $(84.16)^{* * * *}$ & $(15.81)^{* * *}$ & $(3.976)^{* *}$ & $(-1.401)$ & & \\
2007- Sep 2008 Financial Crisis (Eq. 12) & 0.0154 & 0.4824 & 4.6332 & -5.3136 & 0.4069 & $(617.1)^{* * *}$ \\
& $(84.64)^{* * *}$ & $(15.86)^{* * *}$ & $(5.3682)^{* * * *}$ & $(-6.374)^{* * *}$ & & \\
\hline
\end{tabular}

***,** and ${ }^{*}$ denotes to the significance at the level of $1 \%, 5 \%$ and $10 \%$ respectively. () contains the t-statistics 


\section{Additional file}

Additional file 1: Data File. (XLSX $1871 \mathrm{~kb})$

\section{Acknowledgements}

We gratefully acknowledge Dr. Arshad Hassan (Associate Professor, Capital University of Science and Technology, Islamabad) for his valuable suggestions and discussions. We also acknowledge the editorial office and the anonymous referees of this journal.

\section{Availability of data and materials}

The datasets using for estimation of article are included within its Additional file 1.

\section{Authors' contributions}

All authors contributed equally. All authors read and approved the final manuscript.

\section{Ethics approval and consent to participate}

Not applicable.

\section{Consent for publication}

Not applicable.

\section{Competing interests}

The authors declare that they have no competing interests.

\section{Author details}

${ }^{1}$ Management Sciences, Capital University of Science and Technology, Islamabad, Pakistan. ${ }^{2}$ Air University School of Management, Air University, Islamabad, Pakistan. ${ }^{3}$ International Islamic University, Islamabad, Pakistan.

Received: 6 September 2016 Accepted: 25 June 2018

Published online: 14 July 2018

\section{References}

Al-Hajieh H, Redhead K, Rodgers T (2011) Investor sentiment and calendar anomaly effects: a case study of the impact of Ramadan on Islamic middle eastern markets. Res Int Bus Financ 25(3):345-356

Al-Khazali O (2014) Revisiting fast profit investor sentiment and stock returns during Ramadan. Int Rev Financ Anal 33:158-170 Barberis N, Shleifer A, Wurgler J (2005) Co-movement. J Financ Econ 75(2):283-317

Barro RJ, McCleary R (2003) Religion and economic growth. National Bureau of Economic Research No. w9682 Białkowski J, Etebari A, Wisniewski TP (2012) Fast profits: investor sentiment and stock returns during Ramadan. J Bank Financ 36(3):835-845

Bikhchandani S, Sharma S (2000) Herd behavior in financial markets. IMF Staff Pap:279-310

Chang EC, Cheng JW, Khorana A (2000) An examination of herd behavior in equity markets: an international perspective. J Bank Financ 24(10):1651-1679

Chiang TC, Zheng D (2010) An empirical analysis of herd behavior in global stock markets. J Bank Financ 34(8):1911-1921

Christie WG, Huang RD (1995) Following the pied piper: do individual returns herd around the market? Financ Anal J 51(4):31-37

Daradkeh TK (1992) Parasuicide during Ramadan in Jordan. Acta Psychiatr Scand 86(3):253-254

Demirer R, Kutan AM (2006) Does herding behavior exist in Chinese stock markets? J Int Financ Mark Inst Money 16(2):123-142

Devenow A, Welch I (1996) Rational herding in financial economics. Eur Econ Rev 40(3):603-615

Dowling M, Lucey BM (2005) Weather, biorhythms, beliefs and stock returns-some preliminary Irish evidence. Int Rev Financ Anal 14(3):337-355

Easley D, Kleinberg J (2012) Networks, crowds, and markets: reasoning about a highly connected world. Significance 9: 43-44.

Erkens DH, Hung M, Matos P (2012) Corporate governance in the 2007-2008 financial crisis: evidence from financial institutions worldwide. J Corp Finan 18(2):389-411

Freud S (1922) The unconscious. J Nerv Ment Dis 56(3):291-294

Frieder L, Subrahmanyam A (2004) Nonsecular regularities in returns and volume. Financ Anal J 60(4):29-34

Froot KA, Scharfstein DS, Stein JC (1992) Herd on the street: informational inefficiencies in a market with short-term speculation. J Financ 47(4):1461-1484

Fu T (2010) Herding in China equity market. Int J Econ Finance 2(2):148

Galariotis EC, Rong W, Spyrou SI (2015) Herding on fundamental information: a comparative study. J Bank Financ 50:589-598

Hamid, K., Suleman, M. T., Ali Shah, S. Z., Akash, l., \& Shahid, R. (2017). Testing the weak form of efficient market hypothesis: empirical evidence from Asia-Pacific markets. https:/papers.ssrn.com/sol3/papers.cfm?abstract_id=2912908

Henker J, Henker T, Mitsios A (2006) Do investors herd intraday in Australian equities? Int J Managerial Finance 2(3):196-219

Hwang S, Salmon M (2004) Market stress and herding. J Empir Financ 11(4):585-616

Javaira Z, Hassan A (2015) An examination of herding behavior in Pakistani stock market. Int J Emerg Mark 10(3):474-490 Javed, Tariq, Zafar, Nousheen, Hafeez Bilal, Herding Behavior in Karachi Stock Exchange (2013). International Journal of Management Sciences and Business Research, Vol. 2, issue 2. Available at SSRN: https://ssrn.com/abstract=2706337 Kahneman D, Tversky A (1972) Subjective probability: a judgment of representativeness. Cogn Psychol 3(3):430-454 Kahneman D, Tversky A (1979) Prospect theory: an analysis of decision under risk. Econometrica: Journal of the econometric society:263-291 
Kamstra MJ, Kramer LA, Levi MD (2003) Winter blues: a SAD stock market cycle. Am Econ Rev 93(1):324-343 Keynes JM (1937) The general theory of employment. Q J Econ 51(2):209-223

Kim N, Mangi F (2016) What's next for Asia's best-performing stock market? In: Bloomberg Markets Retrieved from https://www.bloomberg.com

Knerr I, Pearl PL (2008) Ketogenic diet: stoking energy stores and still posing questions. Exp Neurol 211(1):11-13 Kremer S, Nautz D (2013) Causes and consequences of short-term institutional herding. J Bank Financ 37(5):1676-1686 Kremer S, Nautz D (2013b) Short-term herding of institutional traders: new evidence from the German stock market. Eur Financ Manage 19(4):730-746

Kumar, A., Page, J. K., \& Spalt, O. G. (2011). Religious beliefs, gambling attitudes, and financial market outcomes. Journal of Financial Economics, 102(3):671-708

Lakonishok J, Shleifer A, Vishny RW (1992) The impact of institutional trading on stock prices. J Financ Econ 32(1):23-43

Lao P, Singh H (2011) Herding behavior in the Chinese and Indian stock markets. J Asian Econ 22(6):495-506

Loewenstein GF, Weber EU, Hsee CK, Welch N (2001) Risk as feelings. Psychol Bull 127(2):267

Malik, S. U., \& Elahi, M. A. (2014). Analysis of herd behavior using quantile regression: evidence from Karachi stock exchange (KSE). MPRA paper no. 55322

Malkiel BG (2003) The efficient market hypothesis and its critics. J Econ Perspect 17(1):59-82

Malkiel BG, Fama EF (1970) Efficient capital markets: a review of theory and empirical work. J Financ 25(2):383-417

Mourdoukoutas, P. (2016). Why Pakistan's market beats China's and India's. Forbes. Retrieved From Http://Www.Forbes.Com/

Nofsinger, J. R., \& Sias, R. W. (1999). Herding and feedback trading by institutional and individual investors. The Journal of finance, 54(6):2263-2295.

Nauman Q (2016) Pakistan Stocks Get MSCI Boost. The Wall Street Journal Retrieved from http://www.wsj.com/articles

Olsen RA (1996) Implications of herding behavior for earnings estimation, risk assessment, and stock returns. Financ Anal J 52(4):37-41

Pantzalis C, Ucar E (2014) Religious holidays, investor distraction, and earnings announcement effects. J Bank Financ 47:102-117

Parker, W. D., \& Prechter, R. R. (2005). Herding: an interdisciplinary integrative review from a sociologic perspective. https://papers.ssrn.com/sol3/papers.cfm?abstract_id=2009898

Renneboog L, Spaenjers C (2012) Religion, economic attitudes, and household finance. Oxf Econ Pap 64(1):103-127

Scharfstein, D. S., \& Stein, J. C. (1990). Herd behavior and investment. The American Economic Review, 465-479.

Seyyed FJ, Abraham A, Al-Hajji M (2005) Seasonality in stock returns and volatility: the Ramadan effect. Res Int Bus Financ 19(3):374-383

Shah MUD, Shah A, Khan SU (2017) Herding behavior in the Pakistan stock exchange: some new insights. Res Int Bus Financ 42:865-873

Shiller RJ (2003) From efficient markets theory to behavioral finance. J Econ Perspect 17(1):83-104

Stulz RM, Williamson R (2003) Culture, openness, and finance. J Financ Econ 70(3):313-349

Saunders EM (1993) Stock prices and Wall Street weather. The American Economic Review 83(5):1337-1345.

Tan L, Chiang TC, Mason JR, Nelling E (2008) Herding behavior in Chinese stock markets: an examination of a and B shares. Pac Basin Financ J 16(1):61-77

Wright WF, Bower GH (1992) Mood effects on subjective probability assessment. Organ Behav Hum Decis Process 52(2): 276-291

Yahyazadehfar, M., Ghayekhloo, S., \& Sadeghi, T. (1985). The influence of investor psychology on regret aversion. http://citeseerx.ist.psu.edu/viewdoc/summary?doi=10.1.1.453.1001

Zafar N, Hassan A (2016) An empirical investigation of herding: case of Karachi stock exchange. Pak J Life Soc Sci 14(2):60-69

\section{Submit your manuscript to a SpringerOpen ${ }^{\circ}$ journal and benefit from:}

- Convenient online submission

- Rigorous peer review

Open access: articles freely available online

- High visibility within the field

- Retaining the copyright to your article

Submit your next manuscript at $>$ springeropen.com 